\author{
KS. MAREK STĘPIEŃ \\ Wydział Prawa Kanonicznego \\ Uniwersytetu Kardynała Stefana Wyszyńskiego
}

\title{
RELACJE KONFERENCJI EPISKOPATU POLSKI Z WŁADZAMI POLSKIEJ RZECZYPOSPOLITEJ LUDOWEJ W DRUGIEJ POLOWIE LAT SIEDEMDZIESIĄTYCH XX WIEKU
}

Treść: Wstęp. - 1. Koncepcje relacji Kościoła w Polsce z władzami PRL i sposoby ułożenia stosunków prawno-społecznych prezentowane przez Konferencję Episkopatu. - 2. Rozmowy prowadzone przez przedstawicieli Konferencji Episkopatu Polski z najwyższymi władzami PRL. - 3. Kontakty na szczeblu Konferencji Episkopatu Polski i kierownictwa Urzędu do Spraw Wyznań. - 4. Wnioski końcowe. - Zakończenie.

\section{Wstęp}

Po zakończeniu drugiej wojny światowej, w końcu lat czterdziestych ubiegłego wieku, biskupi polscy, mając na uwadze przede wszystkim dobro wiernych, podjęli rozmowy z władzami komunistycznymi ${ }^{1}$. W kwietniu 1950 r. zawarto Porozumienie ${ }^{2}$, które jednak

\footnotetext{
${ }^{1}$ Zob. Rys historyczny Komisji Mieszanej - Wspólnej na tle stosunków Kościół Państwo w Polsce 1949-1990, Warszawa (bez daty - dokument sporządzony po 1 stycznia 1980 r., w którym błędnie w tytule wpisano datę 1949-1990, a powinno być 1949-1980), Archiwum Konferencji Episkopatu Polski - adres: Skwer Ks. Kard. S. Wyszyńskiego 6, 01-015 Warszawa (skrót: AKEP), sygn. Archiwum 1980-1989 (skrót: III) 03059, s. 1-2.

${ }^{2}$ Zob. Porozumienie zawarte między przedstawicielami Rządu R.P. i Episkopatu Polskiego, Warszawa 14-04-1950 (uwierzytelniona kopia), AKEP, sygn. Archiwum 1945-1968 (skrót: I) 0304/I; Porozumienie zawarte między przedstawicielami Rządu
} 
nie było realizowane przez władze państwowe. Komuniści wówczas zdecydowali się rozpocząć działania represyjne wobec Kościoła w Polsce. W takiej sytuacji do końca lat sześćdziesiątych ubiegłego wieku stosunki między stronami były złe z $^{3}$

W grudniu 1970 r. w Polsce doszło do strajków i demonstracji robotników. Władze komunistyczne zdecydowały się na użycie broni palnej na Wybrzeżu w Trójmieście. W wyniku tych działań zginęło i zostało rannych wielu robotników ${ }^{4}$. Komuniści doszli do wniosku, że muszą zmienić osoby kierujące Polską Zjednoczoną Partią Robotniczą i Rządem PRL, aby uspokoić nastroje społeczne oraz zadeklarowali chęć normalizacji stosunków z Kościołem w Polsce. W marcu 1971 r. odbyło się spotkanie ówczesnego premiera Piotra Jaroszewicza z kard. Stefanem Wyszyńskim, przewodniczącym Konferencji Episkopatu Polski, który w czasie rozmowy podkreślił, że władze państwowe nie powinny ingerować w sprawy religii i Kościoła oraz krępować jego działalności. Zdaniem prymasa, dotychczasowe złe stosunki między państwem a Kościołem wynikały ze stosowania przez władzę ideologii materialistycznej, gdzie uznawało się każdą religię za czynnik społecznie negatywny. Kardynał Wyszyński oświadczył, że prawdziwa normalizacja wzajemnych stosunków może nastąpić tylko wówczas, jeśli będą spełnione następujące najważniejsze warunki: uznanie przez państwo Kościoła katolickiego jako osoby prawnej prawa publicznego i organizacji społecznej; zaaprobowanie zasady,

Rzeczypospolitej Polskiej i Episkopatu Polski, w dniu 14 kwietnia 1950 r., w: Listy Pasterskie Episkopatu Polski 1945-2000, Aneks, Michalineum 2003, s. 2147-2150.

${ }^{3}$ Zob. Sekretariat Konferencji Episkopatu Polski, Źródła konfliktu między Państwem i Kościołem Katolickim w Polsce, Warszawa 03-09-1969, AKEP, sygn. Archiwum 1969-1979 (skrót: II) 02; Sekretariat Konferencji Episkopatu Polski, Pro memoria w sprawie stosunków Kościoła z Państwem, Warszawa 10-01-1970, AKEP, sygn. II 02, s. 2-3.

${ }^{4}$ Zob. Sprawozdanie z rozmowy przeprowadzonej z Kierownikiem Wydziału Administracyjnego KC PZPR p. St. Kanią w Sulejówku, ul. Żwirowa Nr la dnia 26.I.1971 r. g. 18.30-21.50, Warszawa 27-01-1971, AKEP, sygn. II 031701, s. 2. W czasie spotkania Stanisław Kania poinformował biskupa Bronisława Dąbrowskiego, że na Wybrzeżu było zabitych 48 osób, a rannych 1108. Tamże. 
że Kościół kieruje się własnymi normami prawnymi, a państwo powinno zapewnić swobodę wykonywania w Kościele władzy duchowej i jurysdykcyjnej. Dodatkowo, forum wzajemnych kontaktów miała stanowić reaktywowana Komisja Wspólna przedstawicieli Rządu PRL i Konferencji Episkopatu Polski ${ }^{5}$.

W pierwszej połowie lat siedemdziesiątych ubiegłego wieku nie nastąpiła realna normalizacja stosunków między władzami komunistycznymi a Kościołem w Polsce ${ }^{6}$. Wprawdzie udało się załatwić trzy sprawy: częściowo przywrócić własności Kościoła na Ziemiach Zachodnich i Północnych, umorzyć bezpodstawnie wymierzane czynsze na tych terenach i uchylić obowiązek prowadzenia ksiąg inwentarzowych, to jednak w zasadniczych sprawach komuniści nie zamierzali ustępować i zawierać całościowego porozumienia z Kościołem w Polsce 7 . Wręcz uznali, że będzie lepiej podjąć dwustronne rokowania ze Stolicą Apostolską. W wyniku tych rozmów w lipcu 1974 r. strony podpisały Protokół, na mocy którego Stolica Apostolska i Rząd PRL zobowiązali się ustanowić stałe kontakty robocze realizowane przez zespoły przedstawicieli każdej ze stron. Zespół Rządu PRL rozpoczął swoją pracę w Rzymie przy ambasadzie Polski, natomiast Zespół strony watykańskiej miał w przyszłości przybyć do Warszawy, kiedy Stolica Apostolska uznałaby to za stosowne ${ }^{8}$. Biskupi

${ }^{5}$ Zob. Sprawy omówione z Premierem P. Jaroszewiczem (tekst doręczony), Warszawa 03-03-1971, AKEP, sygn. II 02.

${ }^{6}$ Więcej na ten temat zobacz M. STĘPIEŃ, Relacje Konferencji Episkopatu Polski z władzami Polskiej Rzeczypospolitej Ludowej w pierwszej połowie lat siedemdziesiątych XX wieku, Warszawskie Studia Pastoralne XIII 41 (2018) nr 4, s. 209-232.

${ }^{7}$ Zob. Punkty do rozmowy z Premierem P. Jaroszewiczem (tekst doręczony), Warszawa 20-09-1974, AKEP, sygn. II 02, s. 6-7.

${ }^{8}$ Kopia Protokołu podpisanego przez abpa Agostino Casarolego, sekretarza Rady do Spraw Publicznych Kościoła i Józefa Czyrka, wiceministra spraw zagranicznych PRL. Rzym, 06-07-1974 (polska i włoska wersja językowa), AKEP, sygn. II 0032. Na temat roli Konferencji Episkopatu Polski w rokowaniach Stolicy Apostolskiej z władzami PRL zobacz M. StęPIEŃ, Rola Konferencji Episkopatu Polski w rokowaniach Stolicy Apostolskiej z władzami Polskiej Rzeczypospolitej Ludowej w pierwszej połowie lat siedemdziesiątych XX wieku, Warszawskie Studia Pastoralne XIII 41 (2018) nr 4, s. 233-252. 
polscy zebrani w Warszawie w dniach 15 i 16 stycznia 1975 r. w komunikacie z posiedzenia plenarnego podkreślili, że władze PRL nie podjęły szeregu ważnych spraw z zakresu normalizacji stosunków ${ }^{9}$.

Niniejszy artykuł ma na celu ukazanie relacji Konferencji Episkopatu Polski z władzami Polskiej Rzeczypospolitej Ludowej w drugiej połowie lat siedemdziesiątych ubiegłego wieku.

\section{Koncepcje relacji Kościoła w Polsce z władzami PRL i sposoby ułożenia stosunków prawno-społecznych prezentowane przez Konferencję Episkopatu}

Całościowy obraz wizji relacji Kościoła w Polsce z władzami PRL w drugiej połowie lat siedemdziesiątych ubiegłego wieku znajduje się w obszernym opracowaniu tematów przygotowanych przez kard. Stefana Wyszyńskiego, przewodniczącego Konferencji Episkopatu Polski, przed rozmową z Edwardem Gierkiem, ówczesnym pierwszym sekretarzem KC PZPR. W dokumencie tym zostały uwzględnione następujące kwestie: problem równości obywatelskiej (przeciwstawienie się wszelkiej dyskryminacji); problemy rodziny i moralności społecznej; współdziałania Kościoła i państwa w życiu społeczeństwa i narodu oraz rozwiązania zagadnień społecznych w celu zachowania spokoju w Polsce; rozmów prowadzonych przez Stolicę Apostolską z Rządem PRL; przyjazdu do Polski Jana Pawła II w połowie maja 1979 r. $^{10}$

W rozwinięciu powyższych zagadnień kard. Wyszyński wskazał na koniczność zastosowania zasady wzajemnego współdziałania, w oparciu o prawne uznanie przez państwo miejsca Kościoła w Polsce i suwerenności kraju oraz poszanowania przez państwo wartości kultury narodowej. Prymas Polski postulował wspólne działania na rzecz jedności moralno-politycznej i kulturalnej narodu, na wszystkich płaszczyznach życia w Polsce. Zdaniem kard. Wyszyńskiego, aby

\footnotetext{
${ }^{9}$ Rys historyczny Komisji Mieszanej - Wspólnej na tle stosunków Kościół - Państwo w Polsce 1949-1990, Warszawa (bez daty), AKEP, sygn. III 03059, s. 132.

${ }^{10}$ KARD. S. Wyszyński, Tematy do rozmowy w dniu 24.I.1979, AKEP, sygn. II 031700, s. 1-2.
} 
osiągnąć wyznaczone cele, należałoby uruchomić program formacji narodowo-społecznej, z dowartościowaniem społeczeństwa w życiu politycznym. Jednak tym działaniom przeciwstawiał się monopol rządzącej partii i faktyczne odsunięcie społeczeństwa od właściwych mu zadań. W konsekwencji rządząca partia nie powinna eliminować społeczeństwa z zadań kulturalnych, społecznych, zawodowych, a dać mu możliwość swobodnego działania. Jednak wówczas realia były takie, że partia zastępowała ideologię chrześcijańską indyferentyzmem, laicyzmem, ateizmem i materializmem, stawała się w końcu wyrocznią, przy rozwiązywaniu skomplikowanych problemów życiowych narodu. Zdaniem przewodniczącego Konferencji Episkopatu Polski, w istniejącej sytuacji niezbędna byłaby korekta postępowania w kierunku, aby władza mogła uzyskać zaufanie i zbudować swój autorytet w społeczeństwie, aby zatrzeć podział na „my” i „oni”, i aby całkowicie nie odizolować się od społeczeństwa ${ }^{11}$.

Prymas Polski bardzo mocno podkreślił potrzebę równego traktowania obywateli Polski. Wskazał, że istniał wówczas kontrast między normami zawartymi w ustawie zasadniczej, czyli Konstytucji, a ich praktycznym stosowaniem. Na różnych płaszczyznach dawał się zaobserwować podział wśród obywateli na lepszą i gorszą kategorię, który wyrażał się między innymi w nierównej dystrybucji dóbr ekonomicznych oraz w nierównomiernym zakresie zaopatrywania ludności (tzw. sklepy komercyjne i specjalnego przeznaczenia). Zdaniem kard. Wyszyńskiego, społeczeństwo coraz bardziej było poirytowane uprzywilejowaniem członków partii. Rządzący natomiast powinni być wrażliwi na oszczędne dysponowanie zasobami publicznymi. Ważnym ówcześnie problemem społecznym była rodzina i jej warunki bytowania. Na tym polu, według prymasa, potrzebne byłoby popieranie macierzyństwa przez państwo, poprzez zmiany w statusie pracy zawodowej kobiet, aby w efekcie ograniczać ich pobyt poza rodziną do 5-6 godz. roboczych na dobę, w wymiarze pełnego etatu oraz budowanie większej liczby mieszkań z przeznaczeniem dla rodzin wielodzietnych i ustalenie dla nich priorytetu zaopatrzenia.

\footnotetext{
${ }^{11}$ Tamże, s. 2-5.
} 
Konieczne byłoby też zaprzestanie masowych wysiedleń ludzi z domów jednorodzinnych w dużych miastach, których dokonywano, aby uzyskać grunty pod zabudowę wielorodzinną. Przewodniczący Konferencji Episkopatu Polski podkreślił, że potrzeby obywatela muszą mieć zawsze pierwszeństwo przed dążeniem do zwiększania eksportu państwa ${ }^{12}$.

W dalszym ciągu omawianego dokumentu kard. Stefan Wyszyński zwrócił uwagę na problem moralności społecznej. Na pierwszy plan zostało tu wysunięte zagadnienie zabezpieczenia odpowiednich warunków pracy, także poprzez przyznanie podstawowych praw osobie ludzkiej, przeciwdziałanie biurokratyzacji, korupcji, demoralizacji i wypracowanie właściwych zasad etyki zawodowej. Z tymi kwestiami ściśle związana byłaby walka z nadmiernym spożywaniem alkoholu, szczególnie w czasie pracy. Ważną rolę odgrywał tu system ochrony społecznej i bezpieczeństwa publicznego. Patologiczne zachowania na tym polu to nadmierna i niekontrolowana interwencja państwowego aparatu bezpieczeństwa w życie prywatne, rodzinne i społeczne. W takim stanie rzeczy obywatel stale czuł się podejrzany, kontrolowany i zagrożony. Dodatkowo prymas wskazał na problem pozostawienia w rękach prywatnych własności rolnej, jako nieodzowny warunek wyżywienia społeczeństwa oraz zaprzestania cenzurowania kultury narodowej i nadmiernej eksploatacji siły robotników, bez zapewnienia czasu wolnego w niedziele i święta ${ }^{13}$.

Zdaniem kard. Wyszyńskiego, Kościół był tak skrępowany przez władze administracyjne, że w swej działalności nie mógł wyjść poza obręb świątyń, gdyż naraziłby się na represje. Trwające rozmowy między Episkopatem Polski a władzami PRL nie rozwiązały podstawowych zagadnień, nie ustalono bazy porozumienia, a strona państwowa unikała podjęcia zasadniczych tematów, takich jak uznanie prawno-publicznego charakteru Kościoła, który nie był i nie jest wrogiem, ale użytecznym pomocnikiem w realizowaniu jednego celu, czyli dobra i pomyślności narodu. Niezbędne byłoby tu obopólne

\footnotetext{
12 Tamże, s. 6-10.

${ }^{13}$ Tamże, s. 10-13, 19, 21-22.
} 
zaufanie. Według przewodniczącego Konferencji Episkopatu Polski, Kościół wówczas w szczególności oczekiwał: swobody w obsadzaniu stanowisk kościelnych, gdyż obowiązujący dekret z grudnia 1956 r. w tym względzie wypaczał cele i intencje; swobody wznoszenia świątyń zgodnie z istniejącymi potrzebami; swobody w prowadzeniu działalności religijno-wychowawczej i katechizacji dzieci oraz młodzieży i umożliwieniu celebrowania Mszy św. poza terenami kościelnymi; prawa do organizowania się katolickich środowisk i młodzieży katolickiej; dostępu do radia i telewizji, w celu transmitowania Mszy św. i nadawania audycji dla chorych; swobody działania w wymiarze kultury, przede wszystkim dla katolików świeckich oraz umożliwiania organizowania wydawnictw katolickich i przydziału im papieru w odpowiedniej ilości; swobody działania wyższych seminariów duchownych i zaniechania poboru kleryków do odbywania służby wojskowej; swobody rozwijania nauki katolickiej w wyższych uczelniach katolickich i wydziałach teologicznych, a także swobody w kwalifikacji naukowców i wolności awansów pracowników naukowych ${ }^{14}$.

$\mathrm{Na}$ temat spraw, które w omawianym okresie wymagały rozwiązania $\mathrm{w}$ relacjach $\mathrm{z}$ państwem, wypowiedzieli się biskupi $\mathrm{w}$ dniach 19 i 20 listopada 1975 r. podczas Zebrania Plenarnego Konferencji Episkopatu Polski. Podkreślili oni, że są żywo zainteresowani określeniem statusu prawnego Kościoła w Polsce. Jednocześnie postulowali: wznowienie działalności wydziałów teologicznych w Krakowie, Poznaniu i we Wrocławiu; zaprzestanie powoływania alumnów wyższych seminariów duchownych do odbycia służby wojskowej; zwiększenie liczby zezwoleń na budownictwo sakralne; zwiększenie przydziału papieru dla wydawnictw katolickich i ograniczenie działalności cenzury państwowej ${ }^{15}$.

Obszerne opracowanie na temat relacji Kościoła w Polsce z władzami PRL sporządzono w języku włoskim w Sekretariacie Konferencji Episkopatu Polski w maju 1977 r., z przeznaczeniem, jak się wydaje,

\footnotetext{
${ }^{14}$ Tamże, s. 14-17.

${ }^{15}$ Rys historyczny Komisji Mieszanej - Wspólnej na tle stosunków Kościół - Państwo w Polsce 1949-1990, Warszawa (bez daty), AKEP, sygn. III 03059, s. 133.
} 
przekazania dokumentu do Stolicy Apostolskiej. Opracowanie zostało podzielone na siedem części, gdzie omówiono następujące kwestie: wolności sumienia i wyznania, kontrolowania przez cenzurę państwową środków społecznego przekazu, prawa do wolnego zrzeszania się, enuncjacji propagandowej władz i zagadnienia dotyczące innych problemów, na które napotykał Kościół w Polsce. W końcowej części dokumentu wskazano perspektywy ewentualnego współdziałania między państwem a Kościołem dla dobra narodu i zamieszczono wnioski końcowe ${ }^{16}$. Szczególną uwagę poświęcono dyskryminacji obywateli należących do Kościoła katolickiego, stwierdzając, że nie cieszą się oni pełnią praw obywatelskich, gdyż władze ciągle utrudniają im spełnianie praktyk religijnych. Dotyczyło to zwłaszcza dzieci i młodzieży, które przebywały w internatach, na koloniach i obozach. Osoby wierzące były także dyskryminowane przy podejmowaniu pracy. Władze nie zaprzestały powoływania alumnów wyższych seminariów duchownych do odbywania zasadniczej służby wojskowej, chociaż w Porozumieniu z kwietnia 1950 r. zobowiązały się tego nie czynićc $^{17}$.

W opracowaniu podkreślono, że normalizacja stosunków między Kościołem w Polsce i władzami PRL może nastąpić po zagwarantowaniu Kościołowi następujących fundamentalnych praw:

1. głoszenia prawd wiary i wypełniania misji ewangelizacyjnej;

2. głoszenia nauki społecznej Kościoła;

\footnotetext{
${ }^{16}$ Sekretariat Konferencji Episkopatu Polski, Pro memoria. Problemi riguardanti la normalizzazione dei raporti tra lo Stato e la Chiesa in Polonia, Warszawa 07-05-1977, AKEP, sygn. II 0200.

${ }^{17}$ Tamże, s. 28-29. W 1975 r. wcielono do jednostek wojskowych 86 alumnów. Pochodzili oni z wyższych seminariów duchownych z następujących archidiecezji i diecezji: częstochowska - 3; gnieźnieńska - 2; gorzowska - 7; katowicka - 5; krakowska - 20; łomżyńska - 2; łódzka - 2; warmińska - 6; pelplińska - 4; płocka - 2; poznańska - 4; przemyska - 12; sandomierska - 5; tarnowska - 5; włocławska - 7 . Zestawienie liczbowe Alumnów Wyższych Seminariów Duchownych wcielonych do jednostek wojskowych w latach 1965-1974 i w roku 1975, Warszawa 24-03-1976, AKEP, sygn. II 02.
} 
3. oceniania z punktu widzenia moralnego działań władz świeckich, jeśli te wpływałyby na zbawienie dusz lub ograniczały fundamentalne prawa człowieka;

4. stosowania prawa naturalnego i odwoływania się do niego ${ }^{18}$. Ze swej strony Kościół w Polsce nie oczekiwał żadnych przywilejów w prowadzeniu działalności i uznawał:

1. rzeczywistość polityczną, ekonomiczną i społeczną w PRL;

2. rozdzielenie państwa i Kościoła, z punktu widzenia ich autonomii i niezależności;

3. laickość państwa opartą na pełnej wolności religijnej, tolerancji i równości ${ }^{19}$.

Dalej w dokumencie przedstawiono konkretne sprawy, które wymagały załatwienia, takie jak: uznanie osobowości prawnej Kościoła i jego instytucji przewidzianych przez prawo kanoniczne; uznanie prawa kanonicznego jako prawa wewnętrznego Kościoła; uznanie prawa Kościoła do autonomicznego, zgodnego z prawem kanonicznym mianowania na urzędy kościelne; uznanie prawa do wznoszenia świątyń bez limitów administracyjnych; możliwość swobodnego nauczania prawd wiary, w tym katechizowania dzieci i młodzieży; uznanie prawa Kościoła do kierowania i administrowania seminariami kościelnymi; uznanie prawa Kościoła do wolnego dostępu do prasy, radia i telewizji; zwolnienie alumnów wyższych seminariów duchownych z odbywania zasadniczej służby wojskowej ${ }^{20}$. We wnioskach końcowych zaznaczono, że współpraca Kościoła w Polsce z władzami PRL byłaby możliwa, jeśli państwo zobowiązałoby się do neutralności i praktycznego zagwarantowania wolności religijnej. Nie wystarczałyby tu tylko rozwiązania legislacyjne, ale autentyczne wprowadzenie ich w życie i następnie konsekwentne przestrzeganie ${ }^{21}$.

\footnotetext{
${ }^{18}$ Sekretariat Konferencji Episkopatu Polski, Pro memoria. Problemi riguardanti la normalizzazione dei raport itra lo Stato e la Chiesa in Polonia, Warszawa 07-05-1977, AKEP, sygn. II 0200, s. 32.

${ }^{19}$ Tamże.

20 Tamże, s. 33.

${ }^{21}$ Tamże, s. 34-35.
} 
Prezentowana wówczas przez Konferencję Episkopatu wizja relacji Kościoła w Polsce z władzami PRL i stosunków prawno-społecznych była całościowa i spójna. Postulowano wprowadzenie autentycznej równości wszystkich obywateli bez dyskryminacji i jakichkolwiek nierówności poprzez dowartościowanie społeczeństwa w życiu kulturalnym i politycznym. Niestety, wówczas realnie istniał kontrast między prawami obywateli, które były zapisane w Konstytucji, a ich praktycznym wypełnianiem. Koniecznym było współdziałanie Kościoła w Polsce i państwa w rozwiązywaniu problemów społecznych, takich jak stworzenie odpowiednich warunków pracy; popieranie macierzyństwa poprzez zmiany w statusie pracy zawodowej kobiet, by ograniczać ich pobyt poza rodziną; wspomaganie rodzin wielodzietnych; przeciwdziałanie korupcji biurokratyzacji i nadmiernemu spożywaniu alkoholu, szczególnie w czasie pracy. Niezbędnym było pozostawienie w rękach prywatnych własności rolnej, aby wyżywić wszystkich obywateli, zaprzestanie cenzurowania kultury narodowej i nadmiernej eksploatacji siły robotników, bez zapewnienia czasu wolnego w niedziele i święta.

Kościół w Polsce niezmiennie uważał za niezbędne rozwiązanie kwestii prawnych we wzajemnych stosunkach z państwem, takich jak: uznanie prawno-publicznego charakteru Kościoła, swobody w obsadzaniu stanowisk kościelnych, swobody wznoszenia świątyń, swobody w prowadzeniu działalności religijno-wychowawczej i katechizacji dzieci i młodzieży, swobody działania wyższych seminariów duchownych i zaniechania poboru kleryków do odbycia służby wojskowej, swobody rozwijania nauki katolickiej w wyższych uczelniach katolickich i wydziałach teologicznych.

\section{Rozmowy prowadzone przez przedstawicieli Konferencji Episkopatu Polski z najwyższymi władzami PRL}

W omawianym okresie do częstych i systematycznych kontaktów dochodziło między bp. Bronisławem Dąbrowskim, sekretarzem generalnym Konferencji Episkopatu Polski, a Stanisławem Kanią, zastępcą sekretarza KC PZPR, który był upoważniony do prowadzenia rozmów w imieniu PZPR z przedstawicielami Kościoła w Polsce. 
Biskup Dąbrowski w sporządzonym „Pro memoria do rozmowy z p. St. Kanią dn. 17.XI.1975 r." podkreślił wagę odrzucenia przez władze PRL propozycji wznowienia działalności Komisji Wspólnej przedstawicieli Rządu i Konferencji Episkopatu Polski i określił ten fakt bardzo negatywnie. Zaznaczył też, że mimo nadziei i gotowości ze strony prymasa nie doszło do jego kolejnego spotkania z Prezesem Rady Ministrów. Wskazał, iż następujące problemy nie są załatwione: budowa świątyń, ubezpieczenie społeczne duchowieństwa i zakonników, powoływanie alumnów wyższych seminariów duchownych do odbycia zasadniczej służby wojskowej, normy prawne zawarte w dekrecie Rady Państwa z 31 grudnia 1956 r. o organizowaniu i obsadzaniu stanowisk kościelnych ${ }^{22}$.

Na początku pierwszego, roboczego spotkania w omawianym okresie, które odbyło się w listopadzie 1975 r., bp Bronisław Dąbrowski przedstawił Stanisławowi Kani wszystkie sprawy zamieszczone w Pro memoria, zwracając szczególną uwagę na fakt, że dotychczas nie doszło do trzeciego spotkania prymasa z premierem. Zwrócił uwagę, że mimo zapewnień min. Kazimierza Kąkola, kierownika Urzędu do Spraw Wyznań, nadal były blokowane pozwolenia na budowę nowych świątyń. W 1975 r. obiecywano wydać 49 takich pozwoleń, a faktycznie wydano jedynie 10. Po dwugodzinnym wywodzie bp. Bronisława Dąbrowskiego, Stanisław Kania, zastępca sekretarza KC PZPR, odniósł się do zaprezentowanych spraw. Jego wypowiedź zmierzała do skierowania dyskusji na zagadnienia ekonomiczne kraju i trudności władzy w tym zakresie oraz wzrostu znaczenia PRL w świecie. Przedstawiciel PZPR odniósł się do stosunków państwo - Kościół. Ocenił, że w ostatnich 5 latach w tym względzie zmieniło się dużo, gdyż jego zdaniem aktualnie nie ma konfliktów między Kościołem a państwem. Jednak na wzajemnych stosunkach ciąży piętno powiązania Kościoła na świecie z kapitalizmem i w związku z tym nie ma drogi

\footnotetext{
${ }^{22}$ Zob. Pro memoria do rozmowy z p. St. Kanią dn. 17.XI.1975 r., AKEP, sygn. II 031701.
} 
współdziałania z socjalizmem ${ }^{23}$.Zdaniem Kani, „architekt normalizacji - I Sekretarz - daje Kościołowi szansę i trzeba z niej skorzystać"24. Odniósł się on do możliwości spotkania prymasa z premierem, czy pierwszym sekretarzem i zakończył pytaniami: „Czemu nie? Byłoby to pożyteczne. Ale jak rozmawiać w takiej atmosferze?"25. Jednocześnie podkreślił, że rozmowy są możliwe tylko z kard. Wyszyńskim, a jeśli on złożyłby rezygnację z urzędu, wówczas władze państwowe gotowe są interweniować, aby papież nie przyjął jego rezygnacji, bo jest potrzebny narodowi i Kościołowi. Biskup Dąbrowski, odpowiadając, stwierdził, że prymas Polski nie ustąpi pod dyktatem aparatu bezpieczeństwa władzy komunistycznej, a w obecnej sytuacji należy rozmawiać, a nie grozić. Na zakończenie spotkania Kania stwierdził, że Episkopat Polski nie potrafi wyciągnąć wniosków z wydarzeń, gdyż świat idzie „na lewo”26.

Do następnego spotkania w tym samym gronie doszło w pierwszej połowie stycznia następnego roku, które prawie w całości poświęcone było planowanym zmianom w Konstytucji PRL. Na wstępie Stanisław Kania, wówczas już sekretarz KC PZPR, oświadczył, że VII Zjazd PZPR został pozytywnie oceniony przez Watykan. Natomiast bp Bronisław Dąbrowski podkreślił, że Episkopat jest zaniepokojony planowanymi, daleko idącymi zmianami w Konstytucji, które powodują napięcia w społeczeństwie. Zdaniem biskupa, projekt winien być poddany szerokim konsultacjom społecznym, gdyż społeczeństwo obawia się ograniczenia suwerenności Polski. Zaniepokojenie budziło też ewentualne wyeksponowanie kierowniczej roli partii rządzącej, a to mogło oznaczać dalsze zmonopolizowa nie przez grupę rządzącą praw i odpowiedzialności na wszystkich płaszczyznach życia społecznego ${ }^{27}$.

\footnotetext{
${ }^{23}$ Sprawozdanie z rozmowy przeprowadzonej z p. Stanisławem KANIĄ, Zastępcą Sekretarza KC. Sulejówek, dnia 17.XI.1975 r. godz. 18-23, Warszawa 18-11-1975, AKEP, sygn. II 031701, s. 1-16.

${ }^{24}$ Tamże, s. 16.

25 Tamże.

${ }^{26}$ Tamże, s. 19-20.

${ }^{27}$ Sprawozdanie z rozmowy przeprowadzonej z p. Stan. KANIĄ, Sekretarza KC PZPR w Sulejówku, dnia 8 stycznia 1976 r., g. 17-20, Warszawa 12-01-1976, AKEP, sygn. II 031701.
} 
W omawianym okresie, w czasie spotkań na najwyższym szczeblu władze komunistyczne PRL starały się niejednokrotnie wywierać presje na przedstawicieli Konferencji Episkopatu Polski. Na przykład w czerwcu 1976 r. Stanisław Kania wyraził zaniepokojenie wobec bp. Bronisława Dąbrowskiego, jak określił „stanem wojny” między państwem a Kościołem w Polsce, który jego zdaniem, wypowiedzieli władzom kardynałowie Stefan Wyszyński i Karol Wojtyła oraz bp Ignacy Tokarczuk. Sekretarz KC PZPR oznajmił, że PRL wystąpi do Watykanu o usunięcie z urzędu bp. Tokarczuka i wyraził nadzieję, że Watykan zrozumie tę sytuację. Biskup Dąbrowski stanowczo zaprzeczył, jakoby biskupi zaostrzyli sytuację, gdyż każdy biskup jest zobowiązany do obrony podstawowych praw katolików, gdy są gwałcone. Kościół w Polsce zdaniem bp. Dąbrowskiego nie pozwoli na gwałcenie wolności sumienia, wobec nasilonej walki ideologicznej ze strony władzy i prowadzenia polityki dyskryminacji. Zdaniem Kani, mimo działań biskupów, perspektywy stosunków państwo - Kościół były dobre, gdyż władza nie zamierzała zejść z drogi normalizacji. Na zakończenie spotkania bp Dąbrowski przedstawił problemy, które ciągle nie były rozwiązane. Zaliczył do nich między innymi: trudności z budownictwem sakralnym, dyskryminację w szkołach dzieci i młodzieży ze względu na wyznanie i utrudnianie prowadzenia duszpasterstwa akademickiego, wszechwładzę cenzury, dyskryminację duchownych i zakonników w ubezpieczeniu społecznym, utrudnianie tworzenia i działalności stowarzyszeń katolickich, przeszkadzanie w prowadzeniu procesji Bożego Ciała ${ }^{28}$.

Po upływie około miesiąca doszło do kolejnego spotkania. Tym razem zależało na nim bp. Dąbrowskiemu, gdyż przede wszystkim chciał on interweniować w sprawie robotników represjonowanych za wystąpienia przeciw podwyżce cen żywności. Na początku rozmowy sekretarz generalny Konferencji Episkopatu Polski zwrócił uwagę, że uzgodnienia z poprzedniego spotkania co do przedstawienia spraw

\footnotetext{
${ }^{28}$ Sprawozdanie z rozmowy przeprowadzonej z p. Stan. KANIĄ, Sekretarza KC PZPR w Sulejówku, dn. 23.VI.1976, g. 19-23, Warszawa 01-07-1976, AKEP, sygn. II 031701.
} 
Urzędowi do Spraw Wyznań nie przyniosły efektu, gdyż, jak stwierdzono w Urzędzie, nie otrzymano odpowiednich dyrektyw od władz zwierzchnich. Biskup podkreślił, że traktuje się go tam jak intruza, czy natręta, którego należy zbyć obietnicami bez pokrycia. Biskup Dąbrowski dalej przedstawił fakty wskazujące na działania podejmowane w szkołach przeciwko sumieniu dzieci i rodziców (utrudnianie katechizacji, brak tolerancji religijnej w czasie tzw. kolonii), a także dyskryminację młodzieży akademickiej, w tym alumnów wyższych seminariów duchownych oraz bezwzględnej cenzury państwowej, co jego zdaniem jednoznacznie wskazywało na administracyjną walkę $\mathrm{z}$ religią ${ }^{29}$.

Po tych wstępnych przedłożeniach, sekretarz generalny Konferencji Episkopatu Polski wyraził zaniepokojenie sytuacją społeczno-gospodarczą i wskazał na niebezpieczną walkę władz z ludnością, a w szczególności z robotnikami, poprzez represje i działania odwetowe. Stosowana jednostronna i nachalna propaganda skłaniała nie do spokoju, ale konfrontacji. Kania, odpowiadając, stwierdził, że strukturalna podwyżka cen była konieczna, aby Polakom lepiej się żyło. Wskazał też, że jeśli ktoś nazywa zajścia w Radomiu bohaterstwem, to nadaje się pod sąd i w tym kontekście wymienił bp. Tokarczuka ${ }^{30}$.

W sprawozdaniu z kolejnego spotkania, które miało miejsce na początku grudnia 1976 r., bp Dąbrowski zamieścił uwagę, że rozmowa doszła do skutku w wyniku pretensji wysuwanych przez obie strony, gdyż minister Kąkol, kierownik Urzędu do Spraw Wyznań, ciągle merytorycznie nie odnosił się do przedstawianych spraw i nie było woli ich załatwienia, a Kania podkreślał, że ma poważne zastrzeżenia w stosunku do postawy Episkopatu i poszczególnych jego członków ${ }^{31}$.

Na wstępie rozmowy Kania stwierdził, że dzieje się źle ze stosunkami Episkopat - rząd, gdyż niektórzy biskupi „dali się ponieść

\footnotetext{
${ }^{29}$ Sprawozdanie z rozmowy z Panem St. KANIĄ, Sekretarza KC PZPR w Sulejówku, dnia. 20.VII.1976. Warszawa, 20-07-1976. AKEP, sygn. II 031701, s. 1-3.

${ }^{30}$ Tamże, s. 4-10.

${ }^{31}$ Sprawozdanie z przeprowadzonej rozmowy w Sulejówku z p. St. Kanią, Sekretarza KC PZPR, dnia 3 grudnia 1976 r., g. 14-19. AKEP, sygn. II 031701, s. 1-2.
} 
emocjom". W swych wystąpieniach próbowali utożsamiać się z politycznymi przeciwnikami rządu. Zdaniem przedstawiciela KC PZPR najistotniejszym był stosunek Episkopatu do sytuacji w kraju, a przejściowe kłopoty gospodarcze wiązały się z wejściem na rynek osób z wyżu demograficznego - blisko 2 mln ludzi. W tej sytuacji, jego zdaniem, biskupi zaostrzyli ton wystąpień publicznych i „szermowali hasłem amnestii”. Dalej Kania przyznał, że dochodziło do zwolnień z pracy, bicia robotników przez funkcjonariuszy Milicji Obywatelskiej, ale zaznaczył, że tylko tych, którzy chcieli eskalacji awantur i to oni pierwsi zaatakowali funkcjonariuszy. Zarzucił kard. Wojtyle urządzanie wśród księży zbiórki na apel Komitetu pomocy robotnikom i spotykanie się z przywódcami tego Komitetu w czasie trwania zebrania Konferencji Episkopatu, której wówczas był wiceprzewodniczącym. Jednocześnie Kania wskazał, że bp Tokarczuk swym postępowaniem wypełnił przesłanki wielu artykułów Kodeksu karnego. Sekretarz KC PZPR zadeklarował, że mimo zaistniałych faktów, władze są za kontynuowaniem procesu normalizacji stosunków między Episkopatem i Rządem PRL, a dowodem miały być zezwolenia na budowę nowych kościołów (ok. 300 aktualnie w budowie i 38 zezwoleń wydanych w 1976 r. $)^{32}$.

Odpowiadając, bp Dąbrowski kategorycznie stwierdził, że nie może zgodzić się z wygłoszonymi uogólnieniami i nieprzemyślanymi sformułowaniami. Episkopat jest świadomy, że społeczeństwu potrzebny jest pokój oraz zapewnienie wyżywienia, ale Kościół zna swoją misję w narodzie i ją wypełnia, nie bojąc się prawdy. Nigdy nie zgodzi się na to, aby ideologia marksistowska była panującą w społeczeństwie, wszystkich broni i będzie bronił robotników. Episkopat jest świadomy potrzeby współdziałania Kościoła z państwem w realizacji celów narodowych i społecznych. Dalej podkreślił, że to biskupi pierwsi wyszli z propozycjami współdziałania dla dobra wiernych Kościoła. Natomiast prymas Polski występował przeciwko

\footnotetext{
${ }^{32}$ Tamże, s. 3-6.
} 
zaprogramowanemu ateizmowi i polityce niszczenia dorobku kultury narodowej ${ }^{33}$.

W dalszym ciągu spotkania biskup powrócił do następujących niezałatwionych spraw:

1. restrykcyjnego dekretu o organizowaniu i obsadzaniu stanowisk kościelnych z grudnia 1956 r.;

2. planowania w nowych dzielnicach obszarów pod budowę kościołów;

3. możliwości tworzenia stowarzyszeń;

4. bezpodstawnego dążenia do podporządkowania zgromadzeń zakonnych pod normy prawne odnoszące się do stowarzyszeń ${ }^{34}$;

5. zniesienia ograniczeń zużycia energii w kościołach;

6. zezwolenia na utworzenie kaplic w punktach katechetycznych;

7. dostępu do ubezpieczenia społecznego przez duchownych i osoby zakonne;

8. zwolnienia z odbywania zasadniczej służby wojskowej przez alumnów wyższych seminariów duchownych ${ }^{35}$.

Kania, odpowiadając, wykluczył, aby można było formalnie wyznaczać miejsca na kościoły w nowych dzielnicach miast, natomiast nie dostrzegł trudności w załatwieniu sprawy związanej ze zgromadzeniami zakonnymi, gdyż te oficjalnie nie zostały wpisane do rejestru stowarzyszeń. Mimo że brakowało energii elektrycznej, ale dla kościołów parafialnych limity zostały zniesione, a kwestia dotyczy zgromadzeń zakonnych i ich części mieszkalnych. Zdaniem Kani, ubezpieczeniem społecznym można by było objąć siostry zakonne, które pracują społeczne, ale te, które uczą religii, nie mają tytułu do ubezpieczenia. W odpowiedzi biskup podkreślił, że przedstawione

\footnotetext{
${ }^{33}$ Tamże, s. 7-12.

${ }^{34}$ Prawo o stowarzyszeniach nie było tworzone dla zgromadzeń zakonnych i żadna norma prawna tam zawarta nie da się wprost zastosować dla instytucji zakonnych. Sekretariat Konferencji Episkopatu Polski, Pro memoria na rozmowę w dn. 7.II.1977 r., Warszawa 05-02-1977, AKEP, sygn. II 0301, s. 1-2.

${ }^{35}$ Sprawozdanie z przeprowadzonej rozmowy w Sulejówku z p. St. Kanią, Sekretarza KC PZPR, dnia 3 grudnia 1976 r., g. 14-19, AKEP, sygn. II 031701, s. 13.
} 
rozumowanie jest niewłaściwe, gdyż do ubezpieczenia społecznego mają prawo ci wszyscy, którzy utrzymują się z pracy i mają podpisaną umowę o pracę. Stanisław Kania zwrócił natomiast uwagę, że dekret o organizowaniu i obsadzaniu stanowisk kościelnych jest niewygodny dla Kościoła, ale obowiązuje i nie można z niego zrezygnować, ale władze mogą omówić ten problem, by „uelastycznić” zasady ${ }^{36}$.

Kolejne spotkanie bp. Dąbrowskiego z Kanią odbyło się w pierwszej połowie lutego 1977 r. W czasie rozmowy sekretarz KC PZPR wskazał na dokonania władz zmierzających do poprawy sytuacji gospodarczej i umocnienia pozycji PRL na arenie międzynarodowej. Jak stwierdził, po apelach Episkopatu wszyscy robotnicy zostali zwolnieni z wyjątkiem recydywistów aresztowanych za pospolite przestępstwa, a było ich około 20 osób. Kania podkreślił, że duchowieństwo przejawia poważną, konstruktywną postawę, z wyjątkiem tradycyjnej pary - bp. Tokarczuka i kard. Wojtyły. Kania zaznaczył, że stosunek władz do prymasa jest niezmiennie pozytywny. Takiemu sposobowi przedstawiania rzeczywistości zaprotestował bp Dąbrowski. W swoim wywodzie podkreślił on, że normalizacja stosunków państwo - Kościół nie postępuje od ponad roku. Wydawałoby się, że sprawy są uzgodnione, a faktycznie na niższych szczeblach nie są załatwiane. Dotyczyło to, między innymi, ubezpieczenia społecznego osób zakonnych pracujących w instytucjach kościelnych. W dalszym ciągu bp Dąbrowski po raz kolejny przedstawił kwestie oczekujące rozwiązania, czyli sprawy budownictwa sakralnego, możliwości katechizacji w dniach od poniedziałku do soboty, uregulowania bytu prawnego zgromadzeń zakonnych, działalności cenzury państwowej, w szczególności jeśli to dotyczyło duszpasterskiej działalności Kościoła. Oprócz tego wskazał na konieczność zwolnienia alumnów wyższych seminariów duchownych z odbywania zasadniczej służby wojskowej ${ }^{37}$.

\footnotetext{
${ }^{36}$ Tamże, s. 14-19.

${ }^{37}$ Sprawozdanie z rozmowy przeprowadzonej z p. St. Kanią, Sekr. KC w Sulejówku, 7.II.1977, g. 18-21, Warszawa 08-02-1977, AKEP, sygn. II 031701.
} 
W czasie następnego spotkania Stanisława Kani z bp. Bronisławem Dąbrowskim, które miało miejsce w Sulejówku, dnia 25 maja 1977 r., sekretarz KC PZPR wymienił miejsca: Kraków, Warszawa, Lublin, Gdańsk, Poznań, Łódź, w których, jego zdaniem, głoszone były kazania podburzające społeczeństwo. W tym kontekście wskazał na bp. Tokarczuka, który wygłosił kazanie o morderstwie niewinnego studenta Pyjasa i na kard. Wyszyńskiego, który powiedział, że w Polsce rządzonej przez komunistów człowiek nic nie znaczy i nie myśli się o przyszłych pokoleniach. Kania zapytał rozmówcę, czy to jest nowa linia postępowania Kościoła i jednocześnie zaapelował, aby „powstrzymać politykujących duchownych”. Biskup Dąbrowski odrzucił oskarżenie mieszania się Kościoła w politykę. Oświadczył, że Kościół będzie cały czas pełnił ewangeliczną misję obrony pokrzywdzonych, uciśnionych i dyskryminowanych. Żadne tendencje i ugrupowania polityczne nie potrafią Kościoła sprowokować i odwieść od misji powierzonej mu przez Chrystusa. Następnie stwierdził, że to spotkanie było umówione, aby zająć się następującymi sprawami: działalnością cenzury, służbą wojskową alumnów wyższych seminariów duchownych, katechizacją i wychowaniem, bytem prawnym domów zakonnych, wymogami przedkładania zaświadczeń przez proboszczów wystawianych przez Urząd do Spraw Wyznań, w procedurze załatwiania spraw $\mathrm{z}$ administracją państwową, ubezpieczeniem społecznym duchownych pracujących w instytucjach kościelnych, wyznaczaniem terenów pod budowę kościołów i cmentarzy. W dalszej części rozmowy sekretarz Konferencji Episkopatu Polski przytoczył przykłady dyskryminacji wiernych, deprawowania młodzieży przez prasę, telewizję i specjalne wykłady. Na zakończenie ustalono, że następne spotkanie odbędzie się w drugiej połowie czerwca ${ }^{38}$.

W dniu 29 października 1977 r. pierwszy sekretarz KC PZPR Edward Gierek przyjął w gmachu Sejmu kard. Stefana Wyszyńskiego, przewodniczącego Konferencji Episkopatu Polski. W czasie rozmowy wymieniono poglądy na najważniejsze sprawy narodu i Kościoła.

\footnotetext{
${ }^{38}$ Sprawozdanie z rozmowy przeprowadzonej z p. St. KANIĄ, Sekretarzem KC w Sulejówku dnia 25.V.1977 g. 17-19, Warszawa 26-05-1977, AKEP, sygn. II 031701.
} 
Prymas przedstawił koncepcję normalizacji stosunków Kościoła w Polsce z władzami PRL ${ }^{39}$. Rozmowy te nie przyniosły jednak konkretnych efektów.

Wskazany podczas poprzedniej rozmowy termin spotkania bp. Dąbrowskiego z Kanią nie został dotrzymany. Do spotkania doszło dopiero w drugiej połowie marca $1978 \mathrm{r}$. Wówczas Stanisław Kania ocenił pozytywnie stosunki państwa z Kościołem. Nawiązał do oficjalnej rozmowy Edwarda Gierka, pierwszego sekretarza PZPR z prymasem Polski i audiencji udzielonej Edwardowi Gierkowi przez papieża Pawła VI. Sekretarz KC PZPR zaliczył natomiast do zjawisk niepokojących upolitycznienie działalności duszpasterstwa akademickiego i udostępnianie lokali kościelnych na zebrania antypaństwowe ${ }^{40}$. Biskup Bronisław Dąbrowski uznał, że duszpasterstwo akademickie działa dobrze, co zostało potwierdzone na ostatnim spotkaniu referentów diecezjalnych zajmujących się tymi sprawami. Wszelkie posądzenia o angażowanie się polityczne było oszczerstwem. Natomiast Episkopat ciągle był zaniepokojony zaangażowaniem politycznym księży należących do instytucji „Caritas” utworzonej przez władze państwowe. Sekretarz generalny Konferencji Episkopatu zaproponował, aby dotychczasowe stosunki między państwem a Kościołem w Polsce weszły na pozytywny etap. W tym celu należałoby normalizację przeprowadzić na dwóch poziomach, porzucenia metody „dreptania w miejscu” i dopuszczenie większej swobody w działalności religijno-społecznej Kościoła. Należałoby wspólnie troszczyć się o rodzinę, demografię, wychowanie dzieci i młodzieży, zwalczać biurokrację i korupcję urzędniczą, a także przeciwdziałać innym patologiom społecznym, takim jak: pijaństwu, narkomanii i rozprzężeniu moralnemu. Zwrócił się z postulatem, aby władze pilnie rozpatrzyły następujące zagadnienia: osobowości publiczno-

\footnotetext{
${ }^{39}$ Rys historyczny Komisji Mieszanej - Wspólnej na tle stosunków Kościół - Państwo w Polsce 1949-1990. Warszawa (bez daty), AKEP, sygn. III 03059, s. 139.

${ }^{40}$ Sprawozdanie z rozmowy przeprowadzonej z Sekretarzem KC PZPR Stanisławem Kanią w dniu 20.III.78 g. 18-22, Warszawa, 20-03-1978, AKEP, sygn. II 031701, s. 1-7.
} 
-prawnej Kościoła i zagwarantowania jego swobody działalności na polu wychowawczym oraz kulturalnym, a nade wszystko pełnienia swej misji ewangelizacyjnej. Biskup Dąbrowski ponownie przedstawił konkretne sprawy do załatwienia, które w większości od dawna były już postulowane: uregulowanie sytuacji prawnej Kościoła, zrewidowanie norm prawnych zawartych w dekrecie Rady Państwa z 31 grudnia 1956 r. o organizowaniu i obsadzaniu stanowisk kościelnych, ograniczenie lub zaprzestanie działalności cenzury, ubezpieczenie społeczne osób duchownych i zakonnych, udzielanie zezwoleń na budownictwo sakralne według potrzeb, a nie według woli urzędników państwowych, zezwolenie na celebrowania Mszy św. w punktach katechetycznych, zrezygnowanie z utrudnień organizowania tzw. rekolekcji oazowych, zezwolenie na tworzenie i prowadzenie działalności przez zakłady charytatywne, nadanie Towarzystwu Krzewienia Kultury Świeckiej statusu wyższej użyteczności publicznej, przepisywanie własności nieruchomości od osób fizycznych na rzecz Kościoła ${ }^{41}$.

W odpowiedzi Stanisław Kania wykluczył możliwość złagodzenia lub rezygnacji przez państwo z norm prawnych zawartych w dekrecie o organizowaniu i obsadzaniu stanowisk kościelnych oraz ograniczenia działalności cenzury. Dostrzegł możliwość przydzielania gruntów na budowy sakralne, ale uzależnił to od lepszego klimatu wzajemnych stosunków, jednocześnie zobowiązał się dogłębnie sprawdzić zastrzeżenia dotyczące działalności organizacji „Caritas” zrzeszającej księży, ale wykluczył możliwość zwalczania tych duchownych, gdyż uważał ich za „kadry pozytywne, które współdziałają z Państwem”42. Stanisław Kania zadeklarował, że przekonało go stwierdzenie, iż Kościół nie może działać w próżni, dlatego zwrócił się o bardziej szczegółowe przedstawienie sprawy osobowości publiczno-prawnej Kościoła. Pozytywne załatwienie innych przedstawionych spraw ściśle uzależnił od polepszenia wzajemnych stosunków ${ }^{43}$.

\footnotetext{
${ }^{41}$ Tamże, s. 7-12.

${ }^{42}$ Tamże, s. 12-13.

${ }^{43}$ Tamże, s. 15.
} 
Kolejne rozmowy odbyły się w styczniu 1979 r. Na ich wstępie został ustalony termin spotkania pierwszego sekretarza KC PZPR z prymasem Polski na dzień 24 stycznia 1979 r., o godz. 13.00, w budynku Sejmu. Rozmówcy doszli do wniosku, że spotkanie na najwyższym szczeblu powinno być konstruktywne z konkretnymi konkluzjami i trwać około trzech godzin ${ }^{44}$. W czasie spotkania kard. Stefana Wyszyńskiego z Edwardem Gierkiem kontynuowano wymianę poglądów o najważniejszych sprawach narodu i Kościoła ${ }^{45}$. Prymas przedstawił koncepcję normalizacji stosunków Kościoła w Polsce z władzami $\mathrm{PRL}^{46}$. Także i tym razem nie doszło do przełomu we wzajemnych relacjach i trudno było mówić dalej o postępującej normalizacji.

W lipcu 1979 r. miała miejsce rozmowa bp. Bronisława Dąbrowskiego z Piotrem Jaroszewiczem, Prezesem Rady Ministrów PRL. Głównym tematem spotkania były naciski wywierane na władze centralne przez lokalny aparat partyjny na obszarze diecezji przemyskiej, aby ukarać bp. Ignacego Tokarczuka i współdziałających z nim księży za „nielegalnie” wzniesione świątynie. Premier na wstępie wyraził radość z wizyty Jana Pawła II w Polsce, a jednocześnie ubolewał, że z powodu choroby nie mógł uczestniczyć w powitaniu papieża. Podkreślił, iż wielką siłą Kościoła jest to, że systemy się zmieniają, a on trwa i jest wielkim autorytetem dla wszystkich ludzi. Zaznaczył, że w partii są dogmatycy, którzy nie potrafią pewnych rzeczy zrozumieć i zaakceptować, co prowadzi do wewnętrznych nacisków na władze partyjne. Jak stwierdził, muszą się liczyć z sojusznikami zewnętrznymi i ich wrażliwością, dlatego proces normalizacji stosunków państwa i Kościoła przebiega powoli. Zadeklarował, że władze chcą współdziałać dla dobra narodu, bo Kościół jest w narodzie siłą, której

\footnotetext{
${ }^{44}$ Rozmowa Sekretarza Episkopatu Bpa Bronisława Dąbrowskiego z Sekretarzem KC PZPR St. Kanią w dniu 12.I.79 r. godz. 11.00-12.45 - Pałac w Natolinie, AKEP, sygn. II 031701. Zasadnicza część spotkania dotyczyła ewentualnego przyjazdu do Polski papieża Jana Pawła II. Tamże.

${ }^{45}$ Rys historyczny Komisji Mieszanej - Wspólnej na tle stosunków Kościół - Państwo w Polsce 1949-1990. Warszawa (bez daty), AKEP, sygn. III 03059, s. 148.

${ }^{46}$ Zob. KARD. S. Wyszyński, Tematy do rozmowy w dniu 24.I.1979, AKEP, sygn. II 031700.
} 
nikt nie może lekceważyć. Podkreślił, że on z pierwszym sekretarzem KC PZPR reprezentują linię porozumienia i współdziałania z Kościołem. W odpowiedzi bp Dąbrowski z naciskiem zaznaczył, że Episkopat Polski opowiada się za normalizacją wzajemnych stosunków, ale w terenie przedstawiciele władzy działają przeciwko Kościołowi. Nawiązał do ostatnich wydarzeń i działań prowadzonych przeciwko bp. Tokarczukowi za rzekomo „nielegalne budowle sakralne”. Jaroszewicz stwierdził, że w przedstawionej sprawie jest wyczerpująca dokumentacja. Jeśli Episkopat nie zechce spowodować, aby bp Tokarczuk nie zadrażniał wzajemnych stosunków, to władze dojdą do wniosku, że tych stosunków nie należy normalizować. Dodał, że kierownictwo partii i rządu uważa, iż prymas Polski, nie idąc na żadne ustępstwa ideologiczne, prowadzi politykę pokojowego współdziałania. Biskup Dąbrowski podkreślił, że należy zaspokoić potrzeby ludu wierzącego i wówczas biskup przemyski nie będzie występował z tymi postulatami. Zadaniem sekretarza generalnego Konferencji Episkopatu Polski, to nie bp Tokarczuk rozpoczął walkę, ale dostrzegł w swojej diecezji, że przez wiele lat nie wydawano pozwoleń na budowę kościołów. Wówczas rozmawiał z władzami o tych problemach, ale to nie przynosiło żadnego skutku. Biskup odpowiedział, że jeśli będą zastosowane sankcje wobec biskupa przemyskiego, to cały Episkopat stanie w jego obronie, a także poprze go społeczeństwo polskie i opinia publiczna na świecie. Episkopat nie ulęknie się żadnej siły fizycznej, którą władza może zastosować. Sekretarz generalny Konferencji Episkopatu Polski wyraził ubolewanie, że władze ponownie sięgają po pogróżki. Premier stwierdził, że w tej sprawie są naciski ze trony lokalnych władz partyjnych, ale żadna decyzja na szczeblu centralnym jeszcze nie zapadła. Zadeklarował, że jeśli księża wycofają się z nielegalnie budowanych nieruchomości, to sam osobiście podpisze pozwolenia na budowę kościołów w tych miejscowościach ${ }^{47}$.

${ }^{47}$ Sprawozdanie z rozmowy przeprowadzonej w Urzędzie Rady Ministrów przy Al. Ujazdowskich z Panem Piotrem Jaroszewiczem, Prezesem Rady Ministrów PRL, Warszawa 18 lipca 1979 r. g. 12.30-13.30, Warszawa 19-07-1979, AKEP, sygn. II 0301. 
Ostatnie robocze spotkanie bp. Dąbrowskiego i Kani w latach siedemdziesiątych ubiegłego wieku odbyło się w drugiej połowie października 1979 r. w Sulejówku. Sekretarz generalny Konferencji Episkopatu Polski stwierdził, że ta rozmowa była konieczna ze względu na impas, jaki zaistniał z Urzędem do Spraw Wyznań. Podkreślił, że po wizycie Jana Pawła II wydaje się, że czas jest sposobny, aby przyspieszyć normalizację wzajemnych stosunków, chociaż Episkopat ostatnio odnotował masowy pobór do wojska alumnów wyższych seminariów duchownych. Biskup Dąbrowski stwierdził, że jego zdaniem normalizacja stosunków nie posuwa się naprzód, a raczej można zaobserwować zastój i przyhamowanie oraz torpedowanie działalności Kościoła ze strony władz. Niepokojące jest też, zdaniem biskupa, że nie ma żadnej reakcji na propozycje prymasa Polski przedstawione $\mathrm{w}$ czasie spotkania w styczniu z pierwszym sekretarzem KC PZPR ${ }^{48}$. Następnie po raz kolejny wymienił szczegółowe sprawy, które nie były załatwione: brak pozwoleń na budowę i zorganizowanie wyższych seminariów duchownych w Szczecinie i Koszalinie, ignorowanie postulatów Episkopatu dotyczących utworzenia wydziałów teologicznych w Krakowie, Warszawie, Poznaniu i Wrocławiu, zawieszenie wejścia w życie uzgodnionego okólnika dotyczącego przepisywania własności nieruchomości przez osoby fizyczne na rzecz instytucji kościelnych, postawienie warunków ubezpieczenia społecznego osób duchownych i zakonnych, które nie są do zaakceptowania ${ }^{49}$, przyhamowanie budownictwa sakralnego ze względów ideologicznych, dyskryminowanie Kościoła na polu prowadzenia działalności wydawniczej, poprzez

\footnotetext{
${ }^{48}$ Sprawozdanie z rozmowy przeprowadzonej w dniu 20.X.1979 r. w Sulejówku g. 9-11.30, Warszawa 22-10-1979, AKEP, sygn. II 031701, s. 1-3.

${ }^{49}$ Tamże, s. 3. Władze zakomunikowały, że na ubezpieczenie społeczne duchownych miała być pobierana składka w wysokości $30 \%$ od całości wynagrodzenia (inni wówczas płacili składkę o połowę niższą), jak też wyłączenie z systemu ubezpieczenia osób zatrudnionych w wyższych seminariach duchownych, chyba że Kościół zgodzi się na poddanie seminariów pod nadzór władzy państwowej. Oprócz tego biskup zwrócił uwagę na nękanie i namawianie kleryków do współpracy ze Służbą Bezpieczeństwa. Tamże, s. 3.
} 
ograniczanie przydziału papieru i działalności cenzury, nasilenie akcji ateizacji dzieci i młodzieży ${ }^{50}$.

Stanisław Kania odpowiedział na przedstawione zarzuty w sposób ogólnikowy bez konkretnych zobowiązań. Podkreślił, że władze mogą podejmować przedstawione sprawy (np. budowa seminariów, służba wojskowa alumnów, ZUS) w sposób łączny. Negatywnie ocenił działania bp. Tokarczuka i wyraził zastrzeżenia co do niektórych aspektów poruszanych przez Konferencję Episkopatu Polski w listach pasterskich ${ }^{51}$.

W omawianym okresie dwa razy doszło do spotkania kard. Stefana Wyszyńskiego, przewodniczącego Konferencji Episkopatu Polski, z ówczesnym pierwszym sekretarzem PZPR Edwardem Gierkiem. Rozmowy te nie przyniosły przełomu, a nawet postępu w procesie normalizacji wzajemnych stosunków. W lipcu 1979 r. bp Bronisław Dąbrowski, sekretarz generalny Konferencji Episkopatu Polski, został przyjęty przez Piotra Jaroszewicza, prezesa Rady Ministrów. O spotkanie prosiła strona kościelna, aby omówić naciski wywierane na władze centralne PZPR ze strony lokalnych działaczy partyjnych, by ukarać bp. Ignacego Tokarczuka za rzekome nielegalne budowanie świątyń w diecezji przemyskiej. W czasie rozmowy premier zadeklarował, że władze partii będą opowiadać się za kontynuowaniem procesu normalizacji stosunków między państwem a Kościołem w Polsce, ale jednocześnie zasugerował, że jeśli Episkopat nie powstrzyma bp. Tokarczuka w jego działalności, to władze dojdą do wniosku, że wzajemnych stosunków nie należy normalizować. Ta postawa Piotra Jaroszewicza jest kwintesencją postępowania władz PRL wobec Kościoła w Polsce w drugiej połowie lat siedemdziesiątych ubiegłego wieku. Rozmowy prowadzono, czasami nawet pozytywnie załatwiano poszczególne sprawy, ale nie dopuszczano do kompleksowego porozumienia się w ważnych kwestiach prawnych dotyczących działalności Kościoła w Polsce. Wręcz starano się wywierać presję na

\footnotetext{
50 Tamże, s. 3-4.

${ }^{51}$ Tamże, s. 5-12.
} 
stronę kościelną, aby osiągnąć korzyści polityczne i niejednokrotnie posuwano się do zakamuflowanego szantażu.

Do systematycznych i częstych spotkań dochodziło między bp. Dąbrowskim a Stanisławem Kanią, najpierw zastępcą sekretarza, później sekretarzem KC PZPR, który był upoważniony przez pierwszego sekretarza KC PZPR do prowadzenia rozmów z przedstawicielami Kościoła w Polsce. W sumie w omawianym okresie takich spotkań odbyło się jedenaście. Znamienne jest to, że w czasie jednego z nich Stanisław Kania wręcz oskarżył kardynałów Wyszyńskiego i Wojtyłę oraz bp. Tokarczuka, że wprowadzają wojnę między państwem a Kościołem w Polsce, gdyż występowali w obronie wolności sumienia, w związku z nasiloną walką ideologiczną i dyskryminacją obywateli. Rozmowy prowadzone przez bp. Dąbrowskiego, sekretarza generalnego Konferencji Episkopatu Polski, także nie miały charakteru przełomowego we wzajemnych stosunkach.

\section{Kontakty na szczeblu Konferencji Episkopatu Polski i kierownictwa Urzędu do Spraw Wyznań}

W drugiej połowie lat siedemdziesiątych ubiegłego wieku przedstawiciele Konferencji Episkopatu Polski utrzymywali stałe kontakty z kierownictwem Urzędu do Spraw Wyznań. W listopadzie 1976 r., w czasie jednego z takich spotkań z ministrem Kazimierzem Kąkolem, kierownikiem tego Urzędu, bp Bronisław Dąbrowski bardzo trafnie podsumował metody przyjęte przez przedstawicieli władz niższego szczebla w relacjach z Episkopatem jako „taktyka uśmiechu obietnic i wyciszania"52. Jaskrawym przykładem takiego zachowania, a nawet dezinformacji była obietnica złożona bp. Dąbrowskiemu przez min. Kąkola, że w 1976 r. nie będzie poboru do wojska kleryków wyższych seminariów duchownych. Tę informację sekretarz generalny Konferencji Episkopatu Polski przekazał rektorom seminariów, a w efekcie pobór się odbył. Biskup Dąbrowski w czasie spotkania z min. Kąkolem określił takie działanie jako niedopuszczalne,

\footnotetext{
${ }^{52}$ Sprawozdanie z rozmowy przeprowadzonej w Urzędzie ds. Wyznań w dniu 11.XI.1976 r. z min. Kaz. Kąkolem, Warszawa 11-11-1976, AKEP, sygn. II 0301, s. 2.
} 
wprowadzające w błąd i niszczące zaufanie. Zwrócił też uwagę na, jego zdaniem, niewłaściwe i prowokujące zachowanie min. Kąkola, gdy ten zaprosił kard. Karola Wojtyłę po odbiór paszportu i zaproponował mu przy tej okazji przeprowadzenie dłuższej rozmowy na inne tematy ${ }^{53}$. Nie było to jednak jedyne lekceważące i prowokujące zachowanie przedstawicieli władz wobec metropolity krakowskiego. W liście z listopada 1976 r. skierowanym do bp. Bronisława Dąbrowskiego kard. Karol Wojtyła informował, że od 1972 r. bezskutecznie prosi o spotkanie z Józefem Tejchmą, wicepremierem Rządu PRL, mimo ponowienia prośby w 1974 r. i w październiku 1976 r. $^{54}$

W rozmowach z przedstawicielami Episkopatu Polski wielokrotnie władze państwowe powoływały się na fakty, które po przeprowadzonej weryfikacji okazywały się niemające pokrycia w rzeczywistości. W ten sposób, jak się wydaje, chciano na niższym szczeblu torpedować proces normalizacji. W piśmie z początku listopada $1975 \mathrm{r}$. skierowanym do Kazimierza Kąkola, kierownika Urzędu do Spraw Wyznań, ks. Franciszek Gościński, dyrektor w Sekretariacie Konferencji Episkopatu Polski, stwierdził, że przekazywane stronie kościelnej ostre zarzuty i protesty z powodu rzekomych wrogich aktów wobec państwa nie znalazły potwierdzenia w faktach i przytoczył konkretne przykłady. Mimo to strona rządowa nie wycofywała zarzutów, ani nie wyraziła ubolewania z powodu przekazywania fałszywych informacji. W czasie rozmowy w ostatnim dniu października 1975 r. Aleksander Merker, dyrektor w Urzędzie do Spraw Wyznań, powiadomił ks. Gościńskiego w imieniu władz państwowych, że prowadzona normalizacja z Kościołem w Polsce zostaje zerwana w trybie natychmiastowym, gdyż w katedrze warszawskiej została wmurowana pamiątkowa tablica obrońców Lwowa i bez uściśnięcia ręki niespodziewanie przerwał rozmowy. Ksiądz Gościński podkreślił w piśmie do Kazimierza Kąkola, że takie stawianie sprawy wskazuje na nieznajomość historii, gdyż w czczonym Grobie Nieznanego Żołnierza

\footnotetext{
${ }^{53}$ Tamże.

${ }^{54}$ List. Rada Stała Konferencji Episkopatu Polski do Jana Pawła II, Warszawa 1110-1979, AKEP, sygn. II 0200.
} 
w Warszawie znajdują się szczątki obrońcy Lwowa ${ }^{55}$. W rozmowie z bp. Bronisławem Dąbrowskim min. Kąkol przyznał, że zachowanie dyr. Merkera było niewłaściwe i emocjonalne, nielicujące z postawą urzędnika. Nikt $\mathrm{z}$ władz zwierzchnich nie upoważnił go do złożenia oświadczenia, że rozmowy z Episkopatem zostają zerwane w trybie natychmiastowym. Oprócz tego został zobowiązany do osobistego przeproszenia ks. Gościńskiego za swoje zachowanie. Minister Kąkol wyjaśnił, że władze będą przeciwdziałały poszukiwaniu pretekstów do storpedowania rozmów między Rządem PRL a Kościołem w Polsce ${ }^{56}$.

W czasie 154. Konferencji Episkopatu Polski obradującej w Częstochowie na Jasnej Górze biskupi w dniu 8 września 1976 r. wystosowali do wiernych List Pasterski zatytułowany „Biskupi polscy wzywaja do modlitwy w obronie wiary świętej w Ojczyźnie”, który został odczytany w kościołach w dniu 28 listopada 1976 r., w pierwszą niedzielę Adwentu. Biskupi podkreślili w nim najwyższą wartość wiary i wskazali na niebezpieczeństwa jej zagrażające ${ }^{57}$. W Polskiej Rzeczypospolitej Ludowej, zdaniem Episkopatu, „nie ustała nienawistna, bezwzględna walka z wiarą w Boga i z Kościołem Chrystusowym. (...) $\mathrm{W}$ coraz większym wymiarze nawet instytucje wychowawcze, społeczne i polityczne, podejmują program ateizacji Narodu". Dalej biskupi stwierdzili, że „dla powstrzymania postępu religii, a nawet dla ograniczenia czci Bożej, wykorzystywane są przepisy prawa budowlanego; często odmawia się przez długie lata zezwoleń na budowę kościołów i kaplic..." ${ }^{58}$. W dokumencie Episkopat zaprotestował przeciw: dyskryminacji religijnej w stosowaniu prawa pracy, zaprogramowanej ateizacji, stosowaniu środków prawno-administracyjnych w walce $\mathrm{z}$ religią, szerzeniu antychrześcijańskich zasad moralnych, działaniom

\footnotetext{
${ }^{55}$ Kopia pisma. Ks. F. Gościński do K. Kąkola, Warszawa 03-11-1975, AKEP, sygn. II 02.

${ }^{56}$ Rozmowa z Min. Kąkolem dnia 13.XI.1975, Warszawa 13-11-1975, AKEP, sygn. II 031401.

${ }^{57}$ List. Biskupi polscy wzywają do modlitwy w obronie wiary świętej w Ojczyźnie, Jasna Góra 08-09-1976 (uwierzytelniona kopia przez kard. S. Wyszyńskiego), AKEP, sygn. II 0130.

58 Tamże, s. 3.
} 
godzącym w wiarę dzieci i młodzieży. Biskupi zakończyli List wezwaniem do mężnego wyznawania wiary, posyłania dzieci i młodzieży na katechizację i pielęgnowania wiary w rodzinach ${ }^{59}$.

Do Listu Pasterskiego odniósł się w piśmie skierowanym do bp. Dąbrowskiego, sekretarza generalnego Konferencji Episkopatu Polski, z dnia 21 grudnia 1976 r., min. Kazimierz Kąkol, kierownik Urzędu do Spraw Wyznań. Zarzucił, że „List prezentuje wypaczony obraz stosunków wyznaniowych w naszym kraju; jednostronnie, w sposób dowolny interpretuje niektóre fakty; jednocześnie, co gorsze, kreuje stany nie istniejące” ${ }^{60}$. Dalej minister podkreślił, że „wśród publicznych enuncjacji Episkopatu Polski w historii państwowości socjalistycznej trudno wskazać dokument o podobnie negatywnym wydźwięku” oraz kolejno przytoczył stwierdzenia zawarte w dokumencie Episkopatu. Zakończył pismo następującą konkluzją: „List Pasterski Episkopatu «w obronie wiary świętej w Ojczyźnie» nie może być traktowany jako przejaw dążenia do rzetelnej i rzeczowej oceny sytuacji, nie służy pogłębianiu wzajemnego zrozumienia, które jest nieodzowne w procesie normalizacji stosunków"61. Na pismo odpowiedział bp Dąbrowski w dniu 10 lutego następnego roku, posługując się obszerną argumentacją przygotowaną przez kard. Karola Wojtyłę, wiceprzewodniczącego Konferencji Episkopatu Polski ${ }^{62}$.

W wyjątkowych okolicznościach prymas kard. Stefan Wyszyński interweniował u kierownika Urzędu do Spraw Wyznań. W czerwcu 1978 r. skierował pismo do min. Kazimierza Kąkola, w którym ustosunkował się do powtarzających się zarzutów formułowanych przez

\footnotetext{
59 Tamże, s. 4-7.

${ }^{60}$ Pismo. K. Kąkol do bpa B. Dąbrowskiego, Warszawa 21-12-1976, AKEP, sygn. II 0130.

${ }^{61}$ Tamże.

${ }^{62}$ Pismo. Bp B. Dąbrowski do K. Kąkola, Warszawa 10-02-1977, AKEP, sygn. II 0130. Zob. List. Kard. K. Wojtyła do bpa B. Dąbrowskiego, Kraków 31-12-1976, AKEP, sygn. II 0130; Kard. K. Wojtyła, Propozycje do odpowiedzi na list ministra Kąkola z 21.XII.1976, Kraków 31-12-1976, AKEP, sygn. II 0130.
} 
ten Urząd wobec Kościoła w Polsce ${ }^{63}$. W tym kontekście przewodniczący Konferencji Episkopatu Polski odniósł się do zastrzeżeń rzekomego nadużywania obiektów sakralnych dla celów wykraczających poza sprawowanie kultu religijnego. Chodziło tu przede wszystkim o działanie duszpasterstwa akademickiego. Kardynał podkreślił, że w PRL „obywatel został wyparty z terenu swoich praw"64. Państwo narzuciło obywatelowi tak wiele obowiązków, głównie w dziedzinie gospodarczej i zawodowej, że nie mógł przeznaczać czasu na życie osobiste. Poprzez rozbudowanie ponad miarę systemu milicyjno-infiltracyjnego praktycznie obywatel nie posiada życia prywatnego. W tym kontekście, szkodliwe jest stosowanie dialektyki materialistycznej odnośnie do historii, literatury i kultury narodowej. Społeczeństwo stara się dopełnić braki w wykształceniu, np. w zaangażowaniu się w tzw. "latające uniwersytety”. Prymas zadał retoryczne pytania: czy te wykłady mają charakter polityczny, czy humanistyczny. Czy są wrogie wobec państwa socjalistycznego? Ostrzegł też, że jeśli rządzący będą dalej kopać przepaść między sobą a narodem, może to doprowadzić do niepokojów społecznych ${ }^{65}$.

W październiku 1979 r. doszło do spotkania kard. Wyszyńskiego z min. Kąkolem. Prymas stwierdził wówczas, że nieprawdziwe są deklaracje strony rządowej, iż w Polsce nie ma konfliktów między Kościołem a państwem i że poczyniono na tym polu duży postęp i przechodzi się do fazy współdziałania. Państwo nie ustosunkowało się pozytywnie do następujących postulatów Episkopatu Polski: uregulowania statusu publiczno-prawnego Kościoła, dostępu do środków przekazu, nieskrępowanego prowadzenia działalności społeczno-wychowawczej, zwolnienia alumnów wyższych seminariów duchownych z odbywania służby wojskowej, zezwolenia na wznoszenie budowli sakralnych. W tym stanie faktycznym nasuwa się pytanie, czy władze PRL chcą wzajemnego porozumienia, czy

\footnotetext{
${ }^{63}$ Odpis pisma. Kard. S. Wyszyński do K. Kąkola, Warszawa 10-06-1978, AKEP, sygn. II 02.

${ }^{64}$ Tamże, s. 1.

65 Tamże, s. 2-6.
} 
jest to tylko fasada i wprowadzanie w błąd opinii publicznej. Nie doprowadzono do załatwienia takich spraw jak: zezwolenie na budowę seminariów duchownych w Szczecinie i Koszalinie; utworzenie papieskich wydziałów teologicznych w Krakowie, Warszawie, Poznaniu i we Wrocławiu; uniemożliwienie przepisywania nieruchomości przez osoby fizyczne na rzecz instytucji kościelnych; brak porozumienia w sprawie ubezpieczania społecznego osób duchownych i zakonnych oraz wyłączenie z tego ubezpieczenia osób zatrudnianych w wyższych seminariach duchownych, wcielanie alumnów wyższych seminariów duchownych do służby wojskowej i namawianie ich do podjęcia niejawnej współpracy z organami bezpieczeństwa. Oprócz tego wzmożono akcję ateizacji dzieci i młodzieży, ograniczono przydział papieru dla wydawnictw kościelnych i doprowadzono do bardzo dużej aktywności cenzury państwowej ${ }^{66}$.

Kontakty na szczeblu przedstawicieli Konferencji Episkopatu Polski i Urzędu do Spraw Wyznań dotyczyły załatwiania konkretnych spraw. Ze strony kościelnej w tych rozmowach uczestniczył bp Dąbrowski i ks. Franciszek Gościński z Sekretariatu Konferencji Episkopatu Polski, a ze strony Urzędu jego kierownik w randze ministra Kazimierz Kąkol oraz jego zastępca dyr. Aleksander Merker. W wyjątkowych sprawach interwencje podejmował kard. Stefan Wyszyński. Zazwyczaj najwyższe władze PRL posługiwały się kierownikiem Urzędu do Spraw Wyznań, aby zakomunikować stronie kościelnej swoje niezadowolenie z działalności podejmowanej przez biskupów i poszczególnych księży, które dotyczyło między innymi obrony praw ludzi pracy i szerzej obrony podstawowych praw obywatelskich.

\section{Wnioski końcowe}

W końcu lat siedemdziesiątych ubiegłego wieku biskupi wchodzący w skład Rady Stałej Konferencji Episkopatu Polski, w liście skierowanym do papieża Jana Pawła II, dokonali analizy stosunków Kościół - państwo. Opowiedzieli się tam za kontynuowaniem rozmów

\footnotetext{
${ }^{66}$ Sugestie na spotkanie Prymasa Polski z Ministrem Kąkolem, Warszawa 10-101979, AKEP, sygn. II 031400.
} 
na temat normalizacji na dwóch płaszczyznach: Stolica Apostolska - państwo polskie, Konferencja Episkopatu Polski - Rząd PRL. Wskazali, że należałoby szukać nowych inicjatyw, aby wyjść z zastoju, jaki daje się zaobserwować w stosunkach Kościół - państwo. Podkreślili jednocześnie, że władze PRL dotychczas kontakty z Kościołem traktowały propagandowo i taktycznie, czasem wykorzystując je instrumentalnie do aktualnych celów politycznych. W wyniku takiej postawy, Zespoły do Stałych Kontaktów Roboczych powołane na mocy Protokołu podpisanego przez przedstawicieli Stolicy Apostolskiej i Rządu PRL stały się nieskuteczne i nie spełniały pokładanych w nich nadziei ${ }^{67}$.

W omawianym okresie Episkopat w Polsce nie zawarł żadnych porozumień z władzami komunistycznymi PRL, a w konsekwencji nie nastąpiła normalizacja stosunków państwo - Kościół w Polsce. Strona kościelna była świadoma, że władzy komunistycznej nie zależało na całościowym i kompleksowym uregulowaniu spraw dotyczących statusu prawnego i funkcjonowania Kościoła w Polsce. Taki stan „tymczasowości” pozwalał władzom na przedłużanie załatwiania poszczególnych spraw na różnych szczeblach administracji państwowej. Niejednokrotnie wręcz komuniści wywierali presję na przedstawicielach Konferencji Episkopatu Polski, a czasem próbowali ich szantażować wprowadzeniem dolegliwych przepisów prawa lub przyjęciem niekorzystnej interpretacji już istniejących norm.

W drugiej połowie lat siedemdziesiątych ubiegłego wieku władze komunistyczne utrzymywały kontakty robocze na różnych szczeblach z przedstawicielami Konferencji Episkopatu Polski, ale prowadziły rozmowy w ten sposób, aby do niczego konkretnego nie zobowiązywać się i nie ujawniać stanowiska partii wobec Kościoła w Pol$\mathrm{sce}^{68}$. Bardzo dobrze podsumował wzajemne relacje $\mathrm{z}$ tego okresu bp Dąbrowski, który w czasie jednego z takich spotkań stwierdził, że

${ }^{67}$ List. Członkowie Rady Stałej Konferencji Episkopatu Polski do Jana Pawła II, Warszawa 11-10-1979, AKEP, sygn. II 0200. List podpisali: kard. S. Wyszyński, kard. F. Macharski, abp J. Stroba, abp H. Gulbinowicz, bp I. Tokarczuk, bp J. Rozwadowski, bp L. Kaczmarek, bp B. Dąbrowski.

${ }^{68}$ Zob. Sugestie na spotkanie Prymasa Polski z Ministrem Kąkolem, Warszawa 10-10-1979, AKEP, sygn. II 031400, s. 1. 
władze posługują się w rozmowach taktyką polegającą na składaniu obietnic, przeciąganiu załatwiania spraw i wyciszaniu problemów ${ }^{69}$. Przykładem grania na zwłokę była postawa wicepremiera Józefa Tejchmy, który przez kolejne cztery lata nie spotkał się z kard. Karolem Wojtyłą, ówczesnym wiceprzewodniczącym Konferencji Episkopatu Polski, który prosił o rozmowę, w celu przedstawienia kwestii wymagających załatwienia ${ }^{70}$.

\section{Zakończenie}

W końcu lat czterdziestych ubiegłego wieku Episkopat w Polsce, przede wszystkim dla dobra wiernych, podjął decyzję o podjęciu rozmów z komunistami, którzy kilka lat wcześniej w sposób niedemokratyczny objęli władzę w kraju. W 1950 r. zawarto Porozumienie, które od samego początku nie było realizowane przez władze PRL. Komuniści rozpoczęli działania represyjne wycelowane między innymi w duchowieństwo i wiernych Kościoła katolickiego. Władze do własnych celów politycznych jedynie instrumentalnie wykorzystywały kontakty z Konferencją Episkopatu Polski.

W początku lat siedemdziesiątych ubiegłego wieku nastąpiły zmiany personalne we władzach PZPR i rządu, a Prezes Rady Ministrów zadeklarował chęć normalizacji stosunków państwo - Kościół. Episkopat odpowiedział pozytywnie na tę deklarację. W omawianym okresie drugiej połowy lat siedemdziesiątych ubiegłego wieku nie nastąpiła normalizacja wzajemnych stosunków. Załatwiano jedynie sprawy mniejszej wagi, odkładano rozmowy, przeciągano je i w efekcie nie zawarto porozumienia, na mocy którego doszłoby do kompleksowego, prawnego uregulowania funkcjonowania Kościoła w Polsce. Bezsprzecznie fundamentalnym wydarzeniem we

\footnotetext{
${ }^{69}$ Zob. Sprawozdanie z rozmowy przeprowadzonej w Urzędzie ds. Wyznań w dniu 11.XI.1976 r. z min. Kaz. Kąkolem, Warszawa 11-11-1976, AKEP, sygn. II 0301, s. 2.

${ }^{70}$ List. Kard. K. Wojtyła do bpa B. Dąbrowskiego, Kraków 08-11-1976, AKEP, sygn. II 030. Zob. Pismo. Kard. K. Wojtyła do J. Tejchmy, Kraków 23-10-1976, AKEP, sygn. II 030; List. Kard. K. Wojtyła do bpa B. Dąbrowskiego, Kraków 25-10-1976, AKEP, sygn. II 030.
} 
wzajemnych relacjach był wybór kard. Karola Wojtyły na Stolicę Piotrową, jednak skutki tego faktu w relacjach Stolica Apostolska i Kościoła w Polsce a władze PRL były widoczne znacznie później. W efekcie w latach osiemdziesiątych kontynuowano rozmowy, co w konsekwencji doprowadziło do wynegocjowania, przyjęcia i wejścia w życie ustawy o stosunku państwa do Kościoła katolickiego z maja 1989 r.

\section{Relations of the Conference of the Episcopate of Poland with the authorities of the Polish People Republic in the second half of the seventies of the $20^{\text {th }}$ century}

After the Second World War communists took over the power in Poland. The main purpose of the ruling party was introducing the principles of Marxist philosophy. In the center of ideological fight was the Roman Catholic Church perceived as serious obstacle or even threat in achieving their goals.

In the second half of the seventies of the 20th century, the authorities of the state expressed the readiness to normalize the relationships with the Church in Poland. The talks however did not bring any significant effects. Communists were not going to compromise or to reach the comprehensive agreement with the Conference of the Episcopate of Poland.

SŁowa KLuczowe: Konferencja Episkopatu Polski; Polska Rzeczypospolita Ludowa; relacje; władze komunistyczne

Key words: the Conference of the Episcopate of Poland; Polish People Republic; relations; communist authorities

\section{Nota o Autorze:}

Ks. DR hab. Marek StęPIEŃ, Prof. UKSW - profesor nadzwyczajny w Katedrze Ustroju Kościoła i Kanonicznych Form Życia konsekrowanego, kierownik Zakładu Praw i Obowiązków Wiernych. 